\title{
EDITORIAL
}

\section{The Impact of Covid-19 on Student Affairs and Higher Education in Africa}

\author{
Thierry M. Luescher, ${ }^{\mathrm{i}}$ Birgit Schreiber, ${ }^{\text {ii }}$ Teboho Moja ${ }^{\text {iii }}$ Martin Mandew, ${ }^{\text {iv }}$ W.P. Wahlv ${ }^{\mathrm{v}}$
} Bekele Ayele vi

\section{A Global Pandemic with Local Realities}

Over the course of their history, African universities have had to contend with many crises, and they have learnt to quickly adapt to ensure that conditions for teaching and learning, as well as student development and support, continue. Political turmoil, economic downturns, fiscal austerity, social conflicts, staff and student strikes, virus outbreaks and even civil wars have forced universities into circumstances that require difficult decisions in a context of great uncertainty and complexity (Fomunyam, 2017). While such disaster periods and events often have deeply disruptive effects on the university community, they tend to last a limited time only. However, the choices made during such periods of crisis frequently outlive the crisis itself and come to define a university's functioning well after the crisis has passed (Adedire, 2018; Chetty \& Luescher, 2021).

In the past, crises that impacted African universities were typically limited to a particular region, nation or institution in their scope. In 2020, however, the global Corona virus disease (Covid-19) came to affect universities comprehensively and worldwide in an unprecedented manner (Schreiber \& Ludeman, 2020). African universities across the

i Prof. Thierry M. Luescher is the Research Director for Post-schooling and Work in the Inclusive Economic Development Division of the Human Sciences Research Council (HSRC), Cape Town, South Africa, and Associate Professor: Higher Education affiliated to the University of the Free State, Mangaung, South Africa. ORCid: 0000-0002-6675-0512. Email: tluescher@hsrc.ac.za

ii Dr Birgit Schreiber is a member of the Africa Centre for Transregional Research at Alberts-LudwigUniversität Freiburg, Germany, and the Vice-President of IASAS and a member of the JSAA Editorial Executive. She is a Senior Consultant for Higher Education Leadership and Management and for Stellenbosch University, South Africa. ORCid: 0000-0003-2469-0504. Email: birgitschreiber@sun.ac.za; birgitdewes@gmail.com

iii Prof. Teboho Moja is Clinical Professor of Higher Education, New York University, U.S.A. She is alo a Visiting Research Fellow at the Centre for the Advancement of Scholarship, University of Pretoria, South Africa, and an Extraordinary Professor at the Institute of Post-School Studies, University of the Western Cape, South Africa. She is JSAA's Editor-in-chief. ORCid: 0000-0001-6343-3020. Email: teboho.moja@nyu.edu

iv Dr Martin Mandew is the Principal of the Qwaqwa Campus of the University of the Free State, South Africa.. Email: mandewMDPA@ufs.ac.za

v Dr W.P. Wahl has been involved in student affairs for almost 19 years and currently serves as Director: Student Life at the University of the Free State (UFS), South Africa. ORCid: 0000-0000-0000-0000.

Email: wahlwp@ufs.ac.za

vi Dr Bekele Ayele is a senior lecturer at Kotebe Metropolitan University (KMU), Addis Ababa, Ethiopia. Email: bekeleworkie@gmail.com 
continent needed to respond to the global health threat and state-instituted lockdown restrictions. University leaders across the continent and globally had to decide on various kinds of emergency measures and reimagine teaching and learning and student engagement and support in order to 'save the academic year' (Dell, 2020; Moja, 2021). The leadership of Student Affairs and Services(SAS) were typically part of such decision-making from the start (Schreiber et al., 2020; Perozzi et al., under review). The participation of SAS leaders and practitioners in the decision-making was crucial as they often are the first port of call when students are in dire straits and require support, be it social, psychological counselling, academic advising, student governance related, access to resources, etc. And yet, even SAS practitioners were not quite prepared for the unprecedented crisis that was about to hit the higher education environment locally, on the African continent, and at a global level. This special issue provided SAS practitioners with an opportunity to reflect on their work, its appropriateness, and to implement risk-mitigating strategies even as the crisis was unfolding.

As campus after campus closed, leaving only a remnant of 'essential services' to continue on site in some cases, learning in most universities was either suspended or moved online in some form of 'emergency remote teaching' (Adotey, 2020; Commonwealth of Learning, 2020; Dell \& Sawael, 2020). Similarly, most SAS provision either moved online or was suspended if they were considered 'non-essential' services (Ayele, 2020). Key higher education actors like the Association of African Universities (AAU) swiftly realised that any form of online learning would potentially exclude many students across the continent who would normally benefit from a campus environment that made up for the lack of a conducive home learning environment or provide other forms of essential learning support (AAU, 2020; Schreiber et al., 2020). Thus, on the one hand, the AAU called on African universities to implement online learning urgently, while also urging African governments to invest in digital infrastructure in rural areas and promote access for all those unable to access online educational services (AAU, 2020; Chetty \& Luescher, 2021).

Student Affairs practitioners have been challenged to respond in innovate ways to meet the diverse needs of different students, enhance student learning and development, and advance the social justice imperative that underpins and drives SAS work.

As much as most governments issued "one size fits all” instructions to universities, on the ground the Student Affairs practitioners had to contend with their diverse local realities. Universities with international students and those with students from far-flung regions faced different challenges in assisting their students' speedy return home than others with a more local student body. There are instances where international students were sent home without financial help from their institutions or assistance from home. Some highly resourced universities were able to issue students who did not have electronic devices like a laptop or tablet with such, along with data vouchers and so forth. Some universities who already used advanced online learning platforms were able to expand their use and deliver learning in an advanced online learning environment while others had to improvise (Chetty \& Luescher, 2021). Universities who had a student body made up largely of financially needy students who needed to return to their communities, often permeated by 
crime and violence, needed to mitigate the impact of these factors and support students or bring them back to campus (UNDP, 2020). Some universities, which had faced crisis prior to the Covid pandemic, had experienced Student Affairs staff and programmes that were attuned to crisis and remote contexts (Schreiber et al., 2020).

Considering higher education and SAS in Africa during the Covid-19 pandemic while moving forward, there are a number of lessons we need to keep in mind. Firstly, the experience of past crises on the African continent and beyond teaches that emergency protocols often turn into, or inform, new standard operational policy after a crisis subsides (Chetty \& Luescher, 2021). In light of this, it is clearly imperative to describe and analyse these moments of crisis, the conditions that gave rise to them, the ways the crisis was managed, and the changes in policy and practice that ensued from it, so as to be able to reflect on them, theorise and learn from them.

The closure of institutions coupled with remote teaching, added more pressure on the students and SAS practitioners. The switch to remote teaching laid bare the enormity of the digital divide on the African continent in its starkest and most iniquitous form as students in far-flung remote rural areas were unable to get access to academic programme. Quintana and Quintana (2020) and Händel et al. (2020) indicate that during the pandemic there were many factors that led to compounded anxiety amongst students including "grade anxiety", absence of adequate infrastructure and overall unpreparedness of institutions and students. There were concerns about the mental health of students and staff and in some instances, institutions added more service and resources to address the challenges (Moja, 2020). Some of the issues that came up for students as a result of being removed from their campuses had to do with them not having appropriate learning spaces and an increased food insecurity as they depended on their financial support that includes expenses related to their living expenses. For a foreseeable future there is a strong likelihood of studies to be conducted to extract more of the lessons learned and the long-term impact of the pandemic.

\section{Producing the JSAA Covid-19 Special Issue}

The idea for a special Covid-19 issue of the Journal of Student Affair in Africa was born with an email of one of the founding editors, Prof. Thierry Luescher, to the Editorial Executive of $J S A A$ on 14 March 2020 in which he proposed that: (1) a call for contributions to a special issue should be developed and sent out to SAS practitioners across the African continent and globally; (2) the special issue should publish practitioner reflections on the impact of Covid-19 on SAS in their respective contexts; (3) a task team of editors should be established to oversee the rapid realisation of the special issue. On the same day, JSAA's Editor-in-Chief, Prof. Teboho Moja and the other founding editor, Dr Birgit Schreiber, responded affirmatively. Within a week the task team of editors was established and a call for papers finalised for distribution. Before the end of the month, an advert had been placed in the University World News Africa Edition to call for papers.

The $J S A A$ call for papers was short and to the point:

"The Covid-19 epidemic has sparked an unprecedented challenge for higher education in general and Student Affairs and Services in particular. The different ways that national ministries, higher education 
institutions and Student Affairs departments and units are responding to the challenge and opportunities in different contexts - by means of social distancing, introducing blended and online development, support and learning, closure, etc. - and the way this affects and implicates the provision of co-curricula and student development and support services, the Student Affairs practitioners, as well as students in general and specific student groups, urgently needs to be documented and presents an opportunity for sharing experiences and learning. The Journal of Student Affairs in Africa is preparing a special issue on 'The Impact of Covid-19 on Higher Education and Student Affairs in Africa' in which we publish the research and reflections of Student Affairs practitioners, university leaders, policy makers, researchers, students, and journalists on the impact of Covid-19 in the context of African higher education and other relevant contexts."

The response from the African and global Student Affairs community was extraordinary. By 31 May 2020, the editorial task team had received 110 proposals from SAS practitioners and scholars hailing from Botswana, Eswatini, Ethiopia, Ghana, Ivory Coast, Kenya, Lesotho, Liberia, Malawi, Namibia, Nigeria, Rwanda, South Africa, Sudan, Tanzania, Uganda, Zambia, Zimbabwe, as well as from Bangladesh, Germany, India, the United Arab Emirates and the United States of America. The task of assessing the abstracts fell upon

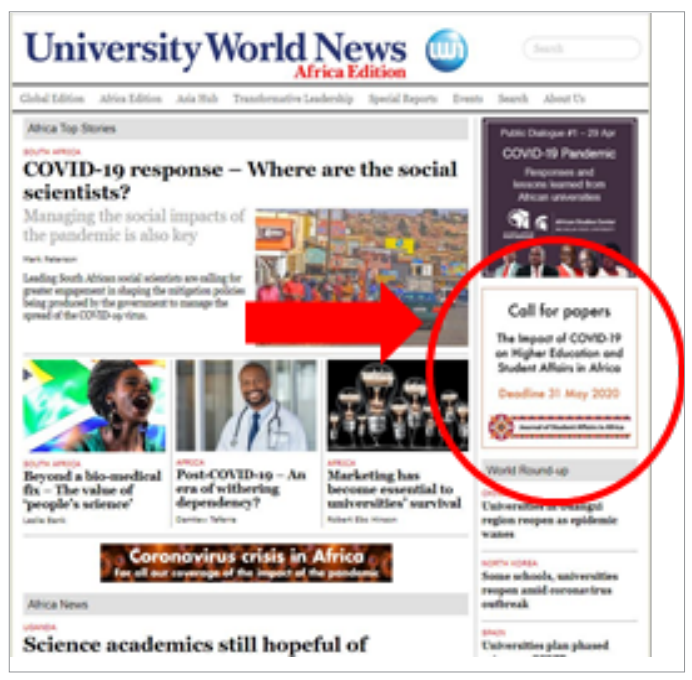
the editors. Within two weeks, they gave the green light to thirty proposals from twelve countries and many more university contexts. Their assessment was guided by the normal assessment criteria of $J S A A$ : scope and interest, originality, significance, and scholarship. Many proposals had to be redirected to journals that focus on teaching and learning in higher education or other specialised aspects like ICT in education.

Within only three months, the authors completed full papers from their proposals. Of the initial thirty accepted proposals, twenty full papers were received and distributed amongst the editorial task team who vetted each of them individually. It was eminently clear that African Student Affairs practitioners had a lot to report on from the impact of the pandemic on their work, staff and students; however, in completing the papers some colleagues were also overrun by crisis work and eventually could not submit. In some cases of submitted papers, the editors requested some corrections from the authors before sending the revised manuscripts to two independent experts for a double-blind review process. The peer review process, which started in December and lasted into late February in some cases, removed a further five papers from the final list. 


\section{The Contents of the Special Issue}

The present special issue is the result of this yearlong process. It is being published while the world is still in the throes of the pandemic, with many countries experiencing a "third wave", while the recently approved vaccines provide the only light at the end of the tunnel. In an analogous sense, this issue presents SAS practitioners' efforts at re-engineering a super-aircraft in mid-flight in an effort to "save the academic year" while "leaving no student behind". As can be seen, it shines like a light in the darkness: in the midst of the tragic of pandemic, a great deal of knowledge has been created. While virologists were developing vaccines, Student Affairs professionals and scholars across Africa invented new ways of operating and supporting the diverse learning needs of future virologists and their peers across the disciplines. The shape and size of the special issue is therefore as follows:

- The issue publishes 15 peer-reviewed articles comprising of eight research articles and seven reflective practitioner accounts.

- There are contributions from seven countries providing in-depth studies from nine different universities.

- Articles focus on career services, disability services, first year students, international students, living and learning support, students with learning disabilities, student governance, Student Affairs staff, the use of student data, and under-resourced students. In addition there is an article that compares the response of SAS to the pandemic in Africa with that of SAS professionals across the globe.

- More than half of the authors are female Student Affairs practitioners and/or researchers.

The first article in this issue is based on a global survey conducted in May 2020 by a group of Student Affairs professionals and scholars from Germany, South Africa, the United Arab Emirates and the United States of America (Schreiber et al., 2021). Their study explores how SAS mediates the impact of personal, socio-cultural and familiar, macro-infrastructural and systemic influences on student success in the context of Covid-19. The article compares survey data collected from SAS practitioners from across the African continent with that of SAS practitioners from other world regions to show the similarities as well as differences in their respective responses to the pandemic. The article proposes a systemiccontextual model of Student Affairs' role in higher education to illustrate the domains that impact on student success and where SAS plays a mitigating role in supporting students.

The second research articles comes from Zambia. In this article Kombe and Mtonga, from Mulungushi University in Kabwe provide empirical evidence in relation to the challenges and interventions of eLearning for under-resourced students in a Zambian public university during the pandemic. This article provides deeper insight into how higher education practitioners and administrators could provide enhanced eLearning support to students, especially students hailing from disadvantaged backgrounds.

Authors Songca, Ndebele and Mbodiba from Walter Sisulu University in South Africa argue that it is unrealistic for universities to advocate for a fully online approach to teaching and learning during Covid-19. They present a model that could be useful to respond to 
Covid-19, underpinned by a framework that accommodates students who choose online learning, students with intermittent access to online and finally students who cannot access online learning.

De Klerk et al. (2021) from the University of the Witwatersrand in South Africa researched the efficacy of an online orientation programme aimed at preparing students to rapidly move to emergency remote learning as a result of a nation-wide lockdown and highlight the need for support of adjustment processes to promote online engagement.

Nyar from the South African National Resource Centre for the First-Year Experience and Students in Transition (SANRC) at the University of Johannesburg, uses the notion of a 'double transition' to conceptualise the two transitions that first-year students face in the context of Covid-19: navigating their entry into the unfamiliar terrain of academia while simultaneously navigating the Covid-19 pandemic. It concludes with four key strategies for supporting first-year students as the pandemic continues.

Kanyumba and Shabangu from the Durban University of Technology conducted a qualitative research study to create a deeper understanding of the ways in which the Covid-19 pandemic influenced the living-learning environment of students in residences.

The broad scope of SAS is highlighted by Manase from the University of the Free State who discusses the pedagogical challenges and opportunities that emerged from remote development, teaching and learning for students who live and learn with disabilities. Her study reveals how some of the Covid-19 related changes offer positive shifts in terms of overcoming social and academic barriers for students with disabilities.

A second study from the University of the Free State by Janeke looks at career development programme in the context of Covid-19. Janeke examines the university's online work readiness programme and illustrates the innovations involved in migrating a career development programme into an online space as well as the impact this career development programme has even under these circumstances.

The set of peer-reviewed reflective practitioner accounts opens with the article by Adjei, Pels and Amoako from Ashesi University in Ghana. Using Schlossberg's Transition Theory the authors analyse the transitional experiences of students amidst the Covid-19 pandemic. Their findings suggest that i) advising, ii) engagement, and iii) timely online support interventions, contributed immensely to students' success in transitioning from in-person to remote learning.

The second reflective article by Dunn-Coetzee and her colleagues at Stellenbosch University in South Africa highlights the challenges that faced Student Affairs professionals when their mode of operation changed quickly to virtual operations. The authors emphasise the importance of making adjustments under those circumstances for the sake of minimising a negative impact on students as well as negative impact on their relationship with students.

Educational technology is used increasingly in the SAS space and Immenga from the University of Cape Town discusses in her article how technological tools can be leveraged to aid in the delivery of co-curricular programmes. Her article particularly deals with the training of class representatives as part of the university's suit of training opportunities for 
students having representative mandates in university governance. She reflects on working with a design team to transition the face-to-face synchronous training of approximately 420 class representatives to an online mode of delivery.

The article by Mutambisi, Murasi and Mazodze from Bindura University of Science Education in Zimbabwe focuses on the pandemic's impacts on the composition, wellbeing and skills requirements of Student Affairs professionals and how the unexpected disengagement with students impacts on SAS. It illuminates some influences which are not immediately visible, but significant. They include having to adjust to new work arrangements, loss of income, mental health problems and resource constrains. Training and development, social media, employee support systems and employee incentives were catalysts in the early adoption of change.

How has the pandemic further complicated the idea of transformation of higher education? A key feature of higher education's response to the pandemic has been the mass migration of the delivery of the curriculum from physical space to cyberspace or Virtual Learning Environments. In her article, Bernard reflects on the problematic and challenging idea of "space" and its impact on the academic project, and specifically on students traditionally categorised as disadvantaged and requiring "special" interventions.

The reflective practitioner account of Chasi and Quinlan illustrates that our lens needs to include international students when deliberating national considerations for higher education. It highlights the specific challenges and constraints that international students faced in light of Covid-19 related restrictions including travel bans, university closures and the national lockdown. They thus explore different aspects of the international student experience including travel home, communication, accommodation and immigration issues.

Finally, Lyner-Cleophas et al. argue that the biggest potential threat of Covid-19 was and still remains the exacerbation of structural inequalities and systemic inequities within the higher education system. How do SAS practitioners practically ensure that students with disabilities are not further excluded as we switch to emergency remote teaching and learning? The authors reflect on the efforts to make existing policies and practices responsive to the needs of students with disabilities in the new and unprecedented environment.

In our 'on campus' section, Bernie Johnson of Wits reflects on the higher education leadership and management (HELM) summit held by Universities South Africa (USAf) in December 2020 and calls explicitly for a wider understanding of factors that support student and university success. She argues that a "supportive political economy is needed for transformation across the sector. We cannot anchor the university if municipalities for example are falling apart in the local contexts". Johnson thus emphasises the role of social, cultural, economic and political context is creating a milieu in which universities and students can indeed be successful, be this in face to face learning or in remote conditions.

Our Covid-19 special issue includes two book reviews. The first is by Tadd Kruse who reviews Learning Online: The Student Experience, authored by George Veletsianos, which puts the student experience into the centre of the learning and development debates. 
The second book review is by Patrick Swanzy who reviews Fred Hayward's Transforming Higher Education in Africa and Asia: Strategic planning and policy (2020). Swanzy highlights that Hayward's discussion on the critical role of strategic planning - be this done intentional or left to unintentional factors - is the critical aspect to building high-quality higher education.

\section{JSA A Organisational}

The Editorial Executive of $J S A A$ would like to announce an exciting development. Since mid-last year we have been in conversation with colleagues in the Education Faculty of the University of Pretoria about hosting the JSAA at Pretoria University. JSAA was founded in 2013 at the University of the Western Cape with technical support from the UWC library and incubation support from the open access scholarly publisher, African Minds. In the course of 2016, the Journal moved to Stellenbosch University, which sponsored a number of issues, hosted and administered the Journal on its e-journal platform, and provided administrative support. We are now happy to announce the move of JSAA to the University of Pretoria's collection of scientific journals. The JSAA Covid-19 Special Issue is the first issue hosted at the University of Pretoria. In addition to hosting the Journal on its e-journal platform (https://upjournals.up.ac.za/index.php/jsaa) and supporting the journal technically, the University of Pretoria has also committed to a level of financial and administrative support for the Journal that will ensure that $J S A A$ continues to operate as a diamond open access journal. This means that we are able to continue to offer free access to our readers (no subscription cost or article-purchase cost) and free publishing for authors (no article processing charges or page fee). We are exceptionally proud of being able to continue this diamond open access format for authors and readers as our contribution to the professionalisation of Student Affairs in Africa.

Finally, the $J S A A$ Editorial Executive wishes to thank the peer reviewers of articles reviewed in 2020 (and, in some cases, published in Volume 8) for their time and expertise. As customary, we list all our distinguished peer reviewers in the first issue of the year. This list serves to certify their commitment to the academic project as trusted peers, and more especially their contribution to the scholarly development and professionalisation of Student Affairs in Africa.

\section{References}

AAU (Association of African Universities) (2020). Appeal to African Ministers of Higher Education: Opportunities for building resilient educational institutions. Accra. https://bit.ly/3sYecv0

Adedire, A.A. (2018). Civil Wars and the African Universities: The University of Ibadan Example, 1967-1970. Ufahamu: A Journal of African Studies, 40(2). https://bit.ly/3aK9BGr

Adotey, S.K. (2020). What will higher education in Africa look like after Covid-19? World Economic Forum. https://bit.ly/2S4Pqwl [Accessed 21 August 2020].

Ayele, B.W. (2020). Life in the time of Covid-19. Ethiopia: The response of Ethiopian Higher Education Institutions to the Covid-19 crisis: SAS is a high focus area. In: R.B. Ludeman \& B. Schreiber (Eds.), Student Affairs and Services in Higher Education: Global Foundations, Issues, and Best Practices (Third edition) (pp. 32-33). IASAS \& Deutsches Studentenwerk (DSW) Publishers. https://bit.ly/3gKOUOf 
Chetty, K. \& Luescher, T.M. (In press, 2021). African Universities - Working towards an inclusive digital future in a post-Covid-19 world. Africa Insight.

Commonwealth of Learning (2020). Guidelines on Distance Education during Covid-19. Burnaby. https://bit.ly/2S92Vv7

Dell, S. (2020, May 15). HE department unveils plan to "save the academic year". University World News (Africa Edition). https://bit.ly/3vnD2Wx

Dell, S. \& Sawahel, W. (2020, 20 March). African universities urged to put classes online urgently. University World News. https://bit.ly/3xxtiLh

Fomunyam, K.G. (2017). Student protest and the culture of violence at African universities: An inherited ideological trait. Yesterday and Today, (17), 38-63. https://doi.org/10.17159/2223-0386/ 2017/n17a3

Händel, M., Stephan, M., Gläser-Zikuda, M., Kopp, B., Bedenlier, S. \& Ziegler, A. (2020). Digital readiness and its effects on higher education students' socio-emotional perceptions in the context of the Covid-19 pandemic. Journal of Research on Technology in Education, 1-13. https://doi.org/ 10.31234/osf.io/b9pg7

Hayward, F. (2020). Transforming Higher Education in Africa and Asia: strategic planning and policy. State University of New York Press.

Moja, T. (2021, January 3). National and institutional responses - reimagined operations - pandemic disruptions and academic continuity for a global university. Studies in Higher Education, 19-29. https://doi.org/10.1080/03075079.2020.1859688

Perozzi, B., Bardill Moscaritolo, L., Schreiber, B. \& Luescher, T.M. (Under review). Global Student Affairs and Services in the Context of Covid-19: Toward a Heuristic Model for SAS Impact on Student Success. Manuscript under review.

Quintana, R. \& Quintana, C. (2020). When classroom interactions have to go online: the move to specifications grading in a project-based design course. Information and Learning Sciences, 121(7/8), 525-532. https://doi.org/10.1108/ILS-04-2020-0119

Schreiber, B., Bardill Moscaritolo, L., Perozzi, B. \& Luescher, T.M. (2020, September 5). The impossibility of separating learning and development. University World News. https://bit.ly/3eDeYIy

Schreiber, B. \& Ludeman, R.B. (2020). Life in the time of Covid-19: Overview. In: R.B. Ludeman $\&$ B. Schreiber (Eds.), Student Affairs and Services in Higher Education: Global Foundations, Issues, and Best Practices (Third edition), (pp. 19-21). IASAS \& Deutsches Studentenwerk (DSW) Publishers. https://bit.ly/3eCUIXr

UNDP (United Nations Development Programme) (2020). Rivera, C., Hsu, Y., Esbry, F., Dugarova, E. (2020). Gender inequality and the Covid-19 crisis. https://bit.ly/2R5i3Jv

Veletsianos, George (2020). Learning Online: The Student Experience. Johns Hopkins University Press.

\section{How to cite:}

Luescher, T.M., Schreiber, B., Moja, T., Mandew, M., Wahl, W.P. \& Ayele, B. (2021). The Impact of Covid-19 on Student Affairs and Higher Education in Africa. Journal of Student Affairs in Africa, 9(1), v-xiii. DOI: 10.24085/jsaa.v9i1.1721 